\title{
PENGARUH PENAMBAHAN KAYU MANIS TERHADAP AKTIVITAS ANTIOKSIDAN DAN KADAR GULA TOTAL MINUMAN FUNGSIONAL SECANG DAN DAUN STEVIA SEBAGAI ALTERNATIF MINUMAN BAGI PENDERITA DIABETES MELITUS TIPE 2
}

\author{
Andriana Murdi Hastuti, Ninik Rustanti ${ }^{*}$ \\ Program Studi Ilmu Gizi Fakultas Kedokteran Universitas Diponegoro \\ J1.Dr.Sutomo No.18, Semarang, Telp (024) 8453708, Email : gizifk@ undip.ac.id
}

\begin{abstract}
Background: Dietary management of Diabetes Melitus type 2 can be done with increasing antioxidant intake and consider both amount and type of carbohydrate. Cinnamon, sappanwood, and stevia leaves are natural sources of antioxidant and has relatively low in total sugar. Hence, these natural sources can be used as ingredient in making of functional drink as an alternative drink for patient with DM type 2.

Objective: To analyze the effect of cinnamon addings on $\mathrm{pH}$ value, brightness level $\left(L^{*}\right)$, antioxidant activity, total sugar and organoleptic aspect that include color, aroma, and flavor of sappanwood and stevia leaves functional drink.

Method: A completely randomized single factor-experimental study by cinnamon addings $(0 \% ; 0,5 \% ; 1,5 \%$ and $2,5 \%)$ on sappanwood and stevia leaves functional drink. Statistical analysis of pH, brightness level ( $\left.L^{*}\right)$, antioxidant activity and total sugar data used One Way ANOVA followed by Tukey test, while organoleptic data was analyzed by Friedman test followed by Wilcoxon test.

Result: The most preferred functional drink by panelist was drink with 1,5\% cinnamon adding with greatest like result on color and like result on aroma and flavor. This functional drink had pH value 6,39; brightness level ( $\left.L^{*}\right)$ 37,10; antioxidant activity 38,43\% and total sugar 4,77\%.

Conclusion: Cinnamon addings on sappanwood and stevia leaves functional decreased antioxidant activity and increased total sugar were not significantly.
\end{abstract}

Keyword: functional drink, cinnamon, sappanwood, stevia leaves, antioxidant activity

\begin{abstract}
ABSTRAK
Latar Belakang: Penatalaksanaan diet diabetes melitus tipe 2 dapat dilakukan dengan meningkatkan asupan antioksidan serta memperhatikan jumlah dan jenis karbohidrat yang dikonsumsi. Kayu manis, secang, dan daun stevia merupakan bahan alami tinggi antioksidan dan rendah gula total yang dapat dijadikan bahan minuman fungsional sebagai alternatif minuman untuk penderita DM tipe 2.
\end{abstract}

Tujuan: Menganalisis pengaruh penambahan kayu manis terhadap pH, tingkat kecerahan ( $\left.L^{*}\right)$, aktivitas antioksidan, gula total dan organoleptik yang meliputi warna, aroma, dan rasa minuman fungsional secang dan daun stevia.

Metode: Merupakan penelitian eksperimental rancangan acak lengkap satu faktor yaitu penambahan kayu manis $(0 \% ; 0,5 \% ; 1,5 \%$ and 2,5\%) pada pembuatan minuman fungsional secang dan daun stevia. Analisis statistik nilai pH, tingkat kecerahan ( $\left.L^{*}\right)$, aktivitas antioksidan, dan gula total menggunakan uji One Way ANOVA dilanjutkan uji Tukey, sedangkan analisis organoleptik menggunakan uji Friedman dilanjutkan uji Wilcoxon.

Hasil: Minuman dengan penambahan kayu manis 1,5\% paling disukai panelis dengan penilaian sangat suka untuk parameter warna dan suka untuk aroma dan rasa. Minuman ini memiliki nilai pH 6,39; tingkat kecerahan (L*) 37,10; aktivitas antioksidan 38,43\%; dan kadar gula total 4,77\%.

Simpulan: Penambahan kayu manis pada minuman fungsional secang dan daun stevia menurunkan aktivitas antioksidan dan menaikkan kadar gula total namun tidak bermakna secara statistik.

Kata kunci: minuman fungsional, kayu manis, secang, daun stevia, aktivitas antioksidan

\section{PENDAHULUAN}

Diabetes Melitus menjadi salah satu masalah kesehatan masyarakat global dan menurut International Diabetes Federation (IDF) tahun 2012, jumlah penderitanya semakin bertambah. Data internasionl dari American Diabetes Association, 90-95\% dari angka kejadian diabetes merupakan diabetes melitus tipe 2. ${ }^{1}$ Diabetes melitus tipe 2 disebabkan oleh penurunan respon jaringan perifer terhadap insulin, peristiwa tersebut dinamakan resistensi insulin. Resistensi insulin mengakibatkan pengaturan glukosa yang tidak terkontrol sehingga terjadi peningkatan kadar glukosa darah atau hiperglikemia. ${ }^{2}$

Hiperglikemia menyebabkan autooksidasi glukosa, glikasi protein, dan aktivasi jalur metabolisme poliol yang mempercepat pembentukan senyawa oksigen reaktif (ROS). 
Pembentukan ROS tersebut dapat meningkatkan modifikasi lipid, DNA, dan protein pada berbagai jaringan. Modifikasi molekuler pada berbagai jaringan mengakibatkan ketidakseimbangan antara pertahanan antioksidan dan radikal bebas. Hal tersebut merupakan awal kerusakan oksidatif (stres oksidatif). ${ }^{3}$

Peningkatan stres oksidatif dapat dihambat oleh antioksidan. Antioksidan merupakan pensetabil radikal bebas yang bekerja dengan cara melengkapi kekurangan elektron radikal bebas dan menghambat terjadinya reaksi berantai dari pembentukan radikal bebas. Upaya untuk meningkatkan pertahanan antioksidan guna menghambat peningkatan stres oksidatif dapat dilakukan dengan cara meningkatkan antioksidan dari luar tubuh. Senyawa non-gizi dalam bahan makanan dapat berperan sebagai antioksidan, seperti senyawa fenol, polifenol, dan flavonoid. ${ }^{4}$

Kayu manis (Cinnamomum burmanii) merupakan bahan makanan sumber antioksidan. Aktivitas antioksidan kayu manis yang diperoleh melalui ekstraksi menggunakan aquades sebesar $45,42 \%$. Kayu manis mengandung sinamaldehid, eugenol, asam sinamat, katekin, epikatekin, dan senyawa polifenol lain. Senyawa fitokimia ini menjadikan kayu manis potensial sebagai antioksidan. ${ }^{5}$ Selain sebagai penambah cita rasa masakan, tumbuhan kayu manis juga mempunyai manfaat kesehatan diantaranya sebagai antihiperglikemi. ${ }^{6}$

Selain kayu manis, bahan yang merupakan bahan sumber antioksidan adalah kayu secang (Caesalpinia sappan L). Ekstrak kayu secang dengan pelarut aquades mempunyai aktivitas antioksidan sebesar $17,62 \%$. Hasil uji ekstrak secang menunjukkan adanya flavonoid, tannin, dan fenolat lainnya yang berpotensi sebagai

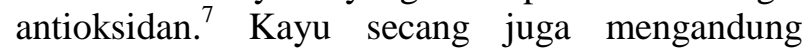
brazilin, yaitu senyawa penghasil warna merah yang termasuk golongan flavonoid. Secang sering digunakan sebagai pewarna alami pada makanan karena dapat menghasilkan warna yang menarik dan dapat diterima secara organoleptik. ${ }^{8}$

Selain memperhatikan asupan antioksidan, asupan gula juga harus diperhatikan. Hal ini dilakukan karena tujuan utama diet diabetes adalah mengendalikan kadar glukosa darah. ${ }^{9}$

Daun stevia (Stevia rebaudiana) merupakan bahan pemanis rendah gula total dan kalori. Rasa manis pada daun stevia berasal dari kandungan glikosida yang terdiri dari 2 komponen utama yaitu steviosida (3-10\% dari berat kering daun) dan rebaudiosida (1-3\% dari berat kering daun). ${ }^{10,11}$ Daun kering stevia mempunyai tingkat kemanisan 2,5 kali dari sukrosa (gula tebu). ${ }^{12}$ Sejak tahun 2008, FDA (Food and Drug Administration) mengijinkan stevia digunakan sebagai bahan tambahan pangan, FDA menggolongkan stevia dalam kategori GRAS (Generally Recognize As Safe) dengan batas konsumsi ADI (Acceptable Daily Intake) sebanyak $4 \mathrm{mg} / \mathrm{kgBB} / \mathrm{hari}{ }^{13}$

Berdasarkan kandungan komponenkomponen aktifnya, kayu manis, secang dan daun stevia potensial untuk dikembangkan menjadi produk minuman fungsional sebagai alternatif minuman tinggi antioksidan serta rendah gula total bagi penderita diabetes melitus tipe $2 .{ }^{14}$

\section{METODE}

Penelitian yang dilakukan termasuk dalam bidang food production. Penelitian dilakukan mulai bulan Februari sampai Juni di Laboratorium Ilmu Gizi dan Teknologi Pangan Universitas Muhammadiyah Semarang dan di Program Studi Ilmu Gizi Universitas Diponegoro Semarang.

Penelitian ini merupakan penelitian eksperimental dengan rancangan acak lengkap satu faktor yaitu penambahan kayu manis (Cinnamomum burmanii) pada minuman fungsional secang (Caesalpinia sappan L) dan daun stevia (Stevia rebaudiana). Terdapat 4 taraf perlakuan $(\mathrm{t}=4)$ yaitu penambahan kayu manis $0 \%$ (kontrol), 0,5\%, 1,5\%, dan 2,5\%. Tiap kelompok perlakuan pada penelitian ini dilakukan 3 kali ulangan sehingga diperoleh 12 satuan percobaan. Penentuan formulasi kayu manis, secang dan daun stevia pada minuman fungsional dilakukan melalui penelitian pendahuluan.

Berdasarkan hasil uji organoleptik terbaik, ditentukan formulasi minuman fungsional kayu manis, secang dan daun stevia sebagai berikut.

Tabel 1. Formulasi Minuman Fungsional Kayu Manis, Secang dan Daun Stevia

\begin{tabular}{cccc}
\hline Perlakuan & $\begin{array}{c}\text { Penambahan } \\
\text { kayu manis }(\boldsymbol{\%})\end{array}$ & $\begin{array}{c}\text { Secang } \\
(\mathbf{\%})\end{array}$ & $\begin{array}{c}\text { Daun stevia } \\
(\boldsymbol{\%})\end{array}$ \\
\hline T0 & 0 & 0,25 & 0,2 \\
T1 & 0,5 & 0,25 & 0,2 \\
T2 & 1,5 & 0,25 & 0,2 \\
T3 & 2,5 & 0,25 & 0,2 \\
\hline
\end{tabular}


Minuman dibuat dengan cara merebus air dan semua bahan yaitu kayu manis, secang, dan daun stevia yang diperoleh dari Pasar Gedhe Surakarta. Setelah air rebusan mendidih, bahan diambil kemudian disaring dengan kain saring berukuran 150 mesh. Prosedur pembuatan minuman fungsional dapat dilihat pada Lampiran 1.

Pada penelitian ini dilakukan pengumpulan data berupa $\mathrm{pH}$ dengan $\mathrm{pH}$ meter, tingkat kecerahan $\left(\mathrm{L}^{*}\right)$ dengan kromameter, aktivitas antioksidan dengan metode DPPH, kadar gula total dengan metode Luff Schoorl, serta organoleptik pada 25 panelis. Semua data yang terkumpul dianalisis menggunakan program SPSS 16. Pengaruh penambahan kayu manis pada minuman fungsional secang, dan daun stevia terhadap nilai
$\mathrm{pH}$, tingkat kecerahan $\left(\mathrm{L}^{*}\right)$, aktivitas antioksidan dan kadar gula total diuji dengan One Way Anova dan dilanjutkan dengan Posthoc Test Tukey untuk mengetahui beda nyata antar perlakuan. Pengaruh penambahan kayu manis terhadap tingkat kesukaan panelis pada parameter warna, aroma, dan rasa diuji menggunakan uji Friedman dan uji lanjut Wilcoxon.

\section{HASIL}

Nilai pH, Tingkat Kecerahan ( $\left.L^{*}\right)$, Aktivitas Antioksidan, dan Kadar Gula Total Minuman Fungsional

Hasil uji aktivitas antioksidan dan kadar gula total kayu manis, secang, dan daun stevia dapat dilihat pada Tabel 2 .

Tabel 2. Hasil uji bahan

\begin{tabular}{lcc}
\hline \multicolumn{1}{c}{ Bahan } & $\begin{array}{c}\text { Aktivitas antioksidan } \\
(\%)\end{array}$ & $\begin{array}{c}\text { Gula total } \\
(\%)\end{array}$ \\
\hline Kayu manis & 14,36 & 1,25 \\
Secang & 60,03 & 0,41 \\
Daun stevia & 89,52 & 5,27 \\
\hline
\end{tabular}

Kayu manis mempunyai aktivitas antioksidan terendah dibandingkan secang dan daun stevia, yakni $14,36 \%$, sedangkan secang dan daun stevia yakni $60,03 \%$ dan $89,52 \%$. Hasil uji kadar gula total, bahan dengan kandungan gula total paling rendah adalah secang yaitu $0,41 \%$ sedangkan kayu manis dan daun stevia yaitu $1,25 \%$ dan $5,27 \%$.

Hasil analisis $\mathrm{pH}$, tingkat kecerahan $\left(\mathrm{L}^{*}\right)$, aktivitas antioksidan, dan kadar gula total minuman fungsional kayu manis, secang, dan daun stevia dapat dilihat pada Lampiran 2 dan Tabel 3.

Tabel 3. Hasil Analisis pH, Tingkat Kecerahan (L*), Aktivitas Antioksidan, dan Kadar Gula Total

\begin{tabular}{cccccc}
\hline Perlakuan & pH & $\begin{array}{c}\text { Tingkat } \\
\text { Kecerahan }\left(\mathbf{L}^{*}\right)\end{array}$ & $\begin{array}{c}\text { Aktivitas } \\
\text { antioksidan } \\
(\boldsymbol{\%})\end{array}$ & $\begin{array}{c}\text { Gula total } \\
(\boldsymbol{\%})\end{array}$ & $\begin{array}{c}\text { Energi } \\
(\mathbf{k k a l})\end{array}$ \\
\hline T0 & $5,7 \pm 0,04^{\mathrm{b}}$ & $41,86 \pm 1,41^{\mathrm{a}}$ & $39,85 \pm 0,85$ & $4,68 \pm 0,17$ & 9,22 \\
$\mathbf{T 1}$ & $6,16 \pm 0,07^{\mathrm{a}}$ & $39,92 \pm 1,20^{\mathrm{ab}}$ & $37,21 \pm 1,61$ & $4,76 \pm 0,06$ & 9,38 \\
$\mathbf{T 2}$ & $6,39 \pm 0,08^{\mathrm{a}}$ & $37,10 \pm 1,03^{\mathrm{b}}$ & $38,43 \pm 0,88$ & $4,77 \pm 0,11$ & 9,40 \\
$\mathbf{T 3}$ & $6,41 \pm 0,18^{\mathrm{a}}$ & $33,97 \pm 0,92^{\mathrm{c}}$ & $38,42 \pm 0,10$ & $4,81 \pm 0,03$ & 9,48 \\
\hline & $\mathrm{p}=0,000$ & $\mathrm{p}=0,000$ & $\mathrm{p}=0,074$ & $\mathrm{p}=0,503$ & \\
\hline
\end{tabular}

Keterangan: Huruf yang berbeda (a,b,c) dibelakang angka menunjukkan adanya perbedaan yang nyata.

Berdasarkan hasil analisis data, penambahan kayu manis menaikkan $\mathrm{pH}$ minuman fungsional $(\mathrm{p}=0,000)$. Semakin banyak kayu manis yang ditambahkan, $\mathrm{pH}$ minuman semakin tinggi. $\mathrm{pH}$ minuman dengan penambahan kayu manis $0,5 \%$; $1,5 \%$ dan $2,5 \%$ berbeda secara nyata terhadap minuman kontrol.

Penambahan kayu manis menurunkan tingkat kecerahan $\left(\mathrm{L}^{*}\right)$ minuman fungsional $(\mathrm{p}=0,000)$.
Semakin banyak kayu manis yang ditambahkan, minuman yang dihasilkan semakin gelap. Tingkat kecerahan $\left(\mathrm{L}^{*}\right)$ minuman fungsional dengan penambahan kayu manis $1,5 \%$ dan $2,5 \%$ berbeda secara nyata terhadap minuman kontrol.

Penambahan kayu manis pada minuman fungsional menunjukkan penurunan aktivitas antioksidan $(\mathrm{p}=0,074)$ dan kenaikan gula total 
$(\mathrm{p}=0,503)$, namun keduanya tidak bermakna secara statistik.

Organoleptik Minuman Fungsional Kayu
Manis, Secang, dan Daun Stevia

Hasil analisis tingkat kesukaan warna, aroma, dan rasa minuman fungsional kayu manis, secang, dan daun stevia dapat dilihat pada Lampiran 3 dan Tabel 4.

Tabel 4. Hasil Analisis Penerimaan Warna, Aroma, dan Rasa Minuman Fungsional

\begin{tabular}{ccccccc}
\hline \multirow{2}{*}{ Perlakuan } & \multicolumn{2}{c}{ Warna } & \multicolumn{2}{c}{ Aroma } & \multicolumn{2}{c}{ Rasa } \\
\cline { 2 - 6 } & Rerata & Ket & Rerata & Ket & Rerata & Ket \\
\hline T0 & $2,28 \pm 0,61^{\mathrm{c}}$ & Netral & $2,68 \pm 0,74^{\mathrm{b}}$ & Netral & $2,72 \pm 0,79$ & Netral \\
T1 & $3,32 \pm 0,85^{\mathrm{b}}$ & Suka & $3,48 \pm 0,65^{\mathrm{a}}$ & Suka & $3,36 \pm 0,81$ & Suka \\
T2 & $4,20 \pm 0,87^{\mathrm{a}}$ & Sangat suka & $3,80 \pm 0,96^{\mathrm{a}}$ & Suka & $3,28 \pm 1,06$ & Suka \\
T3 & $4,00 \pm 0,87^{\mathrm{a}}$ & Suka & $3,60 \pm 1,11^{\mathrm{a}}$ & Suka & $3,04 \pm 0,84$ & Suka \\
\hline & $\mathrm{p}=0,000$ & & $\mathrm{p}=0,002$ & & $\mathrm{p}=0,130$ & \\
\hline
\end{tabular}

Keterangan: Huruf yang berbeda (a,b,c) dibelakang angka menunjukkan adanya perbedaan yang nyata.

Berdasarkan hasil analisis data, penambahan
kayu manis pada minuman fungsional meningkatkan kesukaan panelis dari parameter warna $(\mathrm{p}=0,000)$. Penambahan kayu manis $1,5 \%$ paling disukai oleh panelis dengan kategori penilaian sangat suka. Penambahan $0,5 \%$ dan $2,5 \%$ mempunyai tingkat kesukaan yang sama, yaitu masuk dalam kategori suka. Minuman kontrol dinilai panelis dengan kategori netral.

Penambahan kayu manis juga meningkatkan kesukaan panelis dari parameter aroma $(\mathrm{p}=0,002)$. Penambahan $0,5 \%, 1,5 \%$, dan $2,5 \%$ mempunyai tingkat kesukaan yang sama, yaitu masuk dalam kategori suka, sedangkan minuman kontrol dinilai netral oleh panelis.

Pada parameter rasa, penambahan kayu manis meningkatkan kesukaan penelis walaupun secara statistik tidak bermakna $(\mathrm{p}=0,130)$. Panelis menilai suka pada penambahan $0,5 \% ; 1,5 \%$ dan $2,5 \%$, sedangkan menilai netral pada kontrol.

\section{PEMBAHASAN}

Nilai pH, Tingkat Kecerahan ( $\left.L^{*}\right)$, Aktivitas Antioksidan, dan Kadar Gula Total Minuman Fungsional

\section{Nilai pH}

Penambahan kayu manis meningkatkan nilai $\mathrm{pH}$ pada minuman fungsional secang dan daun stevia. Hasil uji statistik menunjukkan $\mathrm{pH}$ minuman fungsional dengan penambahan $0,5 \%$; $1,5 \%$ dan $2,5 \%$ berbeda secara nyata dengan minuman fungsional kontrol. Nilai $\mathrm{pH}$ minuman fungsional dipengaruhi oleh $\mathrm{pH}$ bahan yang digunakan. Secang merupakan bahan makanan golongan asam dengan $\mathrm{pH} 4,5-5$, sedangkan kayu manis dan daun stevia merupakan golongan alkali dengan nilai $\mathrm{pH}$ berturut-turut 8,5 dan $9 .{ }^{15}$ Semakin banyak penambahan kayu manis, $\mathrm{pH}$ minuman yang dihasilkan semakin tinggi. $\mathrm{pH}$ minuman berhubungan dengan warna yang dihasilkan. Semakin tinggi $\mathrm{pH}$, minuman yang dihasilkan semakin merah tua. Brazilin pada secang berwarna merah pada $\mathrm{pH}$ 6-7 dan pada $\mathrm{pH} 8$ ke atas berwarna merah keunguan. ${ }^{16}$

\section{Tingkat Kecerahan $\left(\mathbf{L}^{*}\right)$}

Minuman fungsional dengan tingkat kecerahan $\left(\mathrm{L}^{*}\right)$ paling tinggi adalah minuman kontrol dengan nilai 41,86 . Semakin banyak kayu manis yang ditambahkan, minuman yang dihasilkan semakin gelap. Penambahan kayu manis 2,5\% menghasilkan minuman yang paling gelap dengan tingkat kecerahan $\left(\mathrm{L}^{*}\right)$ sebesar 33,97. Tingkat kecerahan $\left(\mathrm{L}^{*}\right)$ menunjukkan gelap terang pada suatu produk. Air dapat melarutkan berbagai komponen dalam bahan seperti garam, vitamin, mineral, karbohidrat, dan sejumlah senyawa mikro lainnya termasuk dalam hal ini adalah pigmen. ${ }^{17}$ Tingkat kecerahan $\left(\mathrm{L}^{*}\right)$ pada minuman fungsional kayu manis, secang, dan daun stevia dipengaruhi oleh komponen bahan penyusunnya, yaitu kayu manis, secang, dan daun stevia.

Komponen utama pada kayu manis berupa sinamaldehid. Sinamaldehid selain bersifat antioksidan juga berperan sebagai pemberi aroma dan warna pada minuman. Semakin banyak kadar kayu manis pada minuman fungsional, minuman yang dihasilkan semakin gelap karena sinamaldehid yang larut semakin banyak. ${ }^{18}$ Brazilin pada kayu secang merupakan senyawa penghasil warna merah yang bersifat sedikit larut dalam air dingin dan mudah larut dalam air panas. ${ }^{8,19}$ Selama proses perebusan dalam pembuatan minuman fungsional, pigmen ini akan larut. Pigmen lain yang mempengaruhi tingkat kecerahan $\left(\mathrm{L}^{*}\right)$ minuman adalah klorofil yang terkandung dalam daun stevia. Daun stevia yang digunakan pada 
minuman fungsional ini merupakan daun stevia kering. Pigmen klorofil penghasil warna hijau berubah menjadi coklat akibat proses penjemuran di bawah sinar matahari. Klorofil pada daun stevia akan larut selama proses perebusan. ${ }^{10}$

\section{Aktivitas Antioksidan}

Penambahan kayu manis pada minuman fungsional secang dan daun stevia menurunkan aktivitas antioksidan. Hal ini dapat dilihat dari hasil uji dengan metode DPPH yang menunjukkan bahwa minuman kontrol mempunyai aktivitas paling tinggi dibandingkan minuman perlakuan. Namun penurunan aktivitas antioksidan ini secara statistik tidak bermakna. Pada uji bahan baku, kayu manis mempunyai aktivitas antioksidan paling rendah dibandingkan secang dan daun stevia, yakni $14,36 \%$ sedangkan secang dan daun stevia $60,03 \%$ dan $89,52 \%$. Hasil tersebut tidak sesuai dengan penelitian terdahulu yang menyatakan bahwa aktivitas antioksidan kayu manis sebesar $45,42 \%{ }^{6}$ Hal ini dapat disebabkan adanya perbedaan jenis dan bagian kayu manis yang digunakan. Kayu manis bagian kulit ranting mempunyai aktivitas antioksidan paling tinggi dibandingkan dengan bagian kulit dahan dan kulit batang. ${ }^{20}$

Minuman fungsional kontrol mempunyai aktivitas antioksidan paling tinggi dibandingkan dengan minuman fungsional dengan penambahan kayu manis $0,5 \%$; $1,5 \%$ dan $2,5 \%$, yaitu $39,85 \%$. Penambahan kayu manis tidak mampu meningkatkan aktivitas antioksidan minuman. Hal ini dapat disebabkan adanya komponen fitokimia yang bersifat antagonis. Kayu manis mengandung katekin dan secang mengandung brazilin, keduanya antagonis sebagai antioksidan. Daun stevia selain berfungsi sebagai pemanis, juga mempunyai aktivitas antioksidan yang tinggi. Namun daun ini juga mengandung katekin, sehingga tidak dapat menghasilkan minuman fungsional dengan aktivitas antioksidan tinggi. ${ }^{11}$

Penurunan aktivitas antioksidan juga dapat disebabkan oleh proses pengolahan minuman. Penelitian terdahulu menyebutkan bahwa menurunnya aktivitas antioksidan yang terjadi selama pengolahan disebabkan suhu yang tinggi serta lamanya perebusan. Pemanasan dapat mempercepat oksidasi antioksidan yang terkandung dalam suatu bahan. Oksidasi mengakibatkan penurunan aktivitas antioksidan dengan tingkat berbeda yang dipengaruhi oleh jenis komponen antioksidan dalam bahan tersebut. Pemanasan suhu tinggi dapat mengakibatkan kerusakan komponen tidak tahan panas termasuk senyawa fenol. Proses perebusan selama 2 menit pada suhu $100{ }^{\circ} \mathrm{C}$ menurunkan total fenol dan aktivitas antioksidan sebesar $45-60 \%$ pada jamur Agrocybe cylindracea. ${ }^{21}$ Komponen yang berperan sebagai antioksidan dari ketiga bahan minuman tersebut berasal dari senyawa fenol, sehingga dapat mengakibatkan penurunan aktivitas antioksidan minuman fungsional yang dihasilkan. ${ }^{21}$

Aktivitas antioksidan merupakan parameter yang dapat menggambarkan persentase kemampuan suatu bahan makanan dalam menghambat radikal bebas. Hiperglikemia menyebabkan ketidakseimbangan antioksidan dan radikal bebas pada penderita diabetes karena adanya modifikasi molekuler pada berbagai jaringan. Hal tersebut merupakan awal terjadinya stres oksidatif. ${ }^{3}$ Stres oksidatif pada penderita diabetes akan mengakibatkan berbagai kerusakan oksidatif berupa komplikasi diabetes dan akan memperparah kondisi penderita diabetes. ${ }^{6}$ Komplikasi tersebut meliputi penyakit makrovaskuler (penyakit kardiovaskuler dan hipertensi) dan penyakit mikrovaskuler (diabetes nefropatik, retinopati dan neuropati). ${ }^{22}$ Asupan antioksidan mempunyai peran protektif terhadap progresivitas diabetes. Peran antioksidan sebagai antihiperglikemia telah diteliti pada subjek tikus wistar jantan, menunjukkan bahwa aktivitas antioksidan sebesar $66,82 \%$ dari ekstrak daun pandan wangi mampu menurunkan kadar glukosa darah sebesar $25,72 \%$ dengan dosis pemberian 600 $\mathrm{mg} / \mathrm{kgBB}$ tikus. $^{23}$

Sinamaldehid merupakan senyawa fitokimia yang paling dominan pada kayu manis. Sinamaldehid berperan sebagai antioksidan dengan menghambat aldose reduktase yaitu enzim yang berperan pada jalur poliol, sehingga pembentukan stress oksidatif terhambat. ${ }^{24}$ Senyawa flavonoid pada secang dan daun stevia juga berperan sebagai antioksidan dengan mengikat ion-ion metal (Fe, $\mathrm{Cu}$ ) yang dapat mengkatalisis reaksi yang memproduksi radikal bebas. ${ }^{25}$ Dengan demikian, upaya meningkatkan asupan antioksidan sangat diperlukan agar dapat meminimalisir stres oksidatif sehingga dapat mencegah komplikasi diabetes melitus.

\section{Kadar Gula Total}

Penambahan kayu manis pada minuman fungsional meningkatkan kadar gula total namun secara statistik tidak bermakna. Hal ini disebabkan kadar gula total kayu manis sangat rendah yakni $1,25 \%$. Gula total adalah senyawa karbohidrat yang berupa monosakarida maupun disakarida (glukosa, galaktosa, fruktosa, sukrosa) yang berfungsi memberikan rasa manis dan penyedia 
energi. Penentuan kadar gula total menggunakan metode Luff Schoorl dengan prinsip hidrolisis disakarida dalam sampel menjadi monosakarida. ${ }^{26}$

Minuman fungsional dengan kadar gula total terendah adalah minuman kontrol, yakni $4,68 \%$ dan tertinggi adalah minuman dengan penambahan kayu manis $2,5 \%$, yakni $4,81 \%$. Berdasarkan kandungan gula total tersebut, energi yang dihasilkan minuman fungsional sebesar 9,22 kkal 9,48 kkal per $100 \mathrm{ml}$ minuman. Energi tersebut $60 \%$ lebih rendah jika dibandingkan dengan energi 1 sdt gula pasir (6 gram) yaitu $23,64 \mathrm{kkal}^{27,28}$

Pada penderita diabetes melitus tipe 2 tujuan utama penatalaksanaan diet adalah mengendalikan kadar gula darah. Tujuan tersebut dapat dicapai salah satunya dengan memperhatikan asupan gula dan energi. ${ }^{9}$

Gula total diserap melalui usus halus. Kecepatan penyerapannya berkaitan dengan kecepatan peningkatan kadar gula darah. Makin cepat diserap, makin cepat pula kenaikan kadar gula darah. ${ }^{29}$ Kenaikan kadar gula darah yang tidak terkendali menyebabkan hiperglikemia. Hiperglikemia merupakan tahap awal munculnya diabetes melitus tipe 2 dan komplikasinya. ${ }^{4}$ Semakin tinggi kadar gula total, energi yang dihasilkan semakin tinggi pula. Konsumsi makanan tinggi energi dalam jumlah berlebih berpotensi menaikkan berat badan. Berat badan berlebih berhubungan negatif dengan resistensi insulin. Semakin tinggi derajat kelebihan berat badan, kerja insulin semakin menurun. Hal ini mengarah pada perkembangan diabetes melitus tipe $2 .{ }^{30}$ Minuman fungsional kayu manis, secang dan daun stevia mengandung gula total dan kalori yang rendah sehingga dapat dijadikan alternatif minuman bagi penderita diabetes melitus tipe 2 .

\section{Organoleptik Minuman Fungsional Kayu Manis, Secang, dan Daun Stevia Warna}

Minuman fungsional kontrol menghasilkan warna merah yang kurang tajam. Minuman kontrol tidak mengandung kayu manis, sehingga warna pada minuman ini hanya berasal dari perpaduan antara brazilin pada secang dan klorofil pada daun stevia. Brazilin adalah golongan senyawa yang memberi warna merah dengan struktur $\mathrm{C}_{6} \mathrm{H}_{14} \mathrm{O}_{5}$. Dalam bentuk kristal berwarna kuning sulfur dan larut air. ${ }^{16}$ Pigmen klorofil pada daun stevia tidak menghasilkan warna hijau karena daun stevia yang digunakan berupa daun kering, zat warna hijau telah berubah menjadi coklat selama proses penjemuran. ${ }^{10}$
Minuman dengan penambahan kayu manis $1,5 \%$ sangat disukai panelis. Warna pada minuman ini juga disebabkan kandungan sinamaldehid pada kayu manis yang berwarna kekuningan. Perpaduan ketiga bahan menghasilkan warna merah cerah. Semakin banyak penambahan kayu manis warna yang dihasilkan semakin merah tua. Warna minuman berhubungan dengan $\mathrm{pH}$. Semakin merah tua minuman yang dihasilkan, $\mathrm{pH}$ minuman semakin tinggi. Minuman dengan penambahan kayu manis $2,5 \%$ berwarna merah paling pekat dengan $\mathrm{pH}$ paling tinggi, yaitu 6,41. Hal ini disebabkan pigmen pada secang, yaitu brazilin berwarna merah pada $\mathrm{pH}$ 6-7 dan pada $\mathrm{pH} 8 \mathrm{ke}$ atas berwarna merah keunguan, sedangkan pada $\mathrm{pH}$ 2-3 warna yang dihasilkan kekuningan. ${ }^{16}$

\section{Aroma}

Pada parameter aroma, penambahan kayu manis juga meningkatkan kesukaan panelis. Secang tidak beraroma dan daun stevia cenderung langu. ${ }^{10}$ Namun pada minuman fungsional ini aroma kayu manis sangat dominan sehingga dapat menutup aroma langu daun stevia. Kayu manis berbau wangi dan beraroma khas yang ditimbulkan oleh sinamaldehid dan eugenol. ${ }^{5}$ Semakin banyak kadar kayu manis, aroma minuman semakin tajam. Minuman fungsional dengan penambahan kayu manis $1,5 \%$ menghasilkan aroma wangi kayu manis yang paling disukai panelis.

\section{Rasa}

Minuman fungsional kontrol dinilai netral oleh panelis karena sedikit terasa pahit setelah mengkonsumsi (bitter-aftertaste) sedangkan pada penambahan kayu manis $0,5 \% ; 1,5 \%$ dan $2,5 \%$, panelis menyatakan suka karena rasa kayu manis dapat menyamarkan bitter-aftertaste tersebut. Secang selain tidak beraroma, juga tidak berasa. Rasa pada minuman fungsional berasal dari kayu manis dan daun stevia. Kandungan sinamaldehid dan eugenol kayu manis selain menimbulkan aroma wangi, juga menimbulkan rasa yang khas kayu manis. 5 Pemanis minuman ini adalah daun stevia kering yang mempunyai tingkat kemanisan 2,5 kali dari sukrosa. ${ }^{12}$ Rasa manis pada daun stevia berasal dari kandungan glikosida yang terdiri dari 2 komponen utama yaitu steviosida (3$10 \%$ dari berat kering daun) dan rebaudiosida (1$3 \%$ dari berat kering daun). ${ }^{10,11}$ Stevia dalam bentuk daun kering dapat mengurangi bitteraftertaste. Rebaudiosida A merupakan komponen yang menimbulkan bitter-aftertaste. Dalam bentuk ekstrak, bitter-aftertaste lebih terasa. Penelitian terdahulu menyebutkan bahwa penambahan stevia 
dalam bentuk ekstrak kurang dari $0,5 \%$ masih dapat diterima secara sensori. ${ }^{31}$

\section{SIMPULAN}

Penambahan kayu manis pada minuman fungsional secang dan daun stevia menurunkan aktivitas antioksidan dan menaikkan kadar gula total namun tidak bermakna secara statistik.

\section{SARAN}

Perlu dilakukan penelitian lebih lanjut tentang pengembangan pangan fungsional tinggi antioksidan berbasis secang dan daun stevia dengan penambahan bahan lain untuk memberikan aroma dan menyamarkan bitter-aftertaste.

\section{DAFTAR PUSTAKA}

1. American Diabetes Association (AdbA). Diagnosis and Classification of Diabetee Melitus. Diabetes Care, 2011.

2. Evans JL, Goldfine ID, Maddux BA, Grodsky GM. Oxidative stres and stres-activated signaling pathways: a unifying hypothesis of type 2 diabetes. Endocrine Reviews 2002; 23:599-622

3. Nuttal SL, Dunne F, Kendal MJ, Martin U. Ageindependent oxidative stres in elderly patiens with non-insulin dependent diabetes melitus. Q J Med 1999;92:33-8.

4. Widowati. Potensi Antioksidan sebagai Antidiabetes. JKM. Bandung. 2008;7:1-10

5. Qin B, Panickar KS, Anderson RA. Cinnamon: Potential role in the prevention of insulin resistance, metabolic syndrome, and type 2 diabetes. Journal of Diabetes Science and Technology. 2010;4(3):685-693.

6. Wang R, Yang B. Extraction of essential oils from five cinnamon leaves and identification of their volatile compound compositions. Innov Food Sci and Emerging Technol. 2009;10:289-292

7. Lutfia, Zahrotul. Ekstraksi dan Identifikasi Kandungan Senyawa pada Kayu Secang (Caesalpinia sappan Linn) serta Uji Aktivitasnya sebagai Antioksidan. [Skripsi]. Malang: Jurusan Kimia FMIPA Universitas Negeri Malang; 2011

8. Nirmagustina Eva. Organoleptic Properties and Phenol Total Content of Traditional Spices Drink (Secang Drink). Jurnal Teknologi Industri dan Hasil Pertanian.1 Maret 2011;16

9. American Diabetes Association. Dietary carbohydrate (amount and type) in prevention and management of diabetes. (Statement). Diabetes Care. 2004;27:2266-74.

10. Abou Esmat. Physico-chemical assessment of natural sweeteners steviosides produced from Stevia rebaudiana bertoni plant. Afr J of Food Sci. May 2010; 4(5):269-281
11. Mishra N. An Analysis of antidiabetic activity of Stevia rebaudian extract on diabetic patient. J Natural Sci Research. 2011;1(3):1-10

12. Buchori. Pembuatan Gula Non Karsinogenik Non Kalori dari Daun Stevia. Semarang: Fakultas Teknik Undip. Desember 2007;11(2):57-60

13. Raini Mriana, Ani Inawati. Safety and Effect of Stevia as a Sweetener. Media Litbang Kesehatan. 2011;21(4)

14. Widyaningsih T.D. Pangan Fungsional: Makanan Untuk Kesehatan. Universitas Brawijaya Malang; 2006

15. Barnett Anne. Examining Food Technology. Heinemann Education Publishers; 1996

16. Maharani, K. Stabilitas pigmen brazilein pada kayu secang (Caesalpinia sappan L.). [Skripsi]. Institut Pertanian Bogor; 2003

17. Winarno F.G. Kimia Pangan dan Gizi. Jakarta: PT Gramedia Pustaka Utama; 2004

18. Yulianto R.A. Formulasi Minuman Herbal Berbasis Cincau Hitam, Jahe, dan Kayu Manis. Jurnal Pangan dan Agroindustri. Oktober 2013; 1:65-77

19. Holinesti R. Studi Pemanfaatan Pigmen Brazilein Kayu Secang (Caesalpinia sappan L.) sebagai Pewarna Alami serta Stabilitasnya pada Model Pangan. Jurnal Pendidikan dan Keluarga UNP. 2009;1(2):11-21

20. Latief M. Aktivitas Antioksidan Ekstrak Metanol Beberapa Bagian Tanaman Kayu Manis (Cinnamomum Burmani) Asal Kabupaten Kerinci Provinsi Jambi. Prosiding Semirata FMIPA Universitas Lampung; 2013

21. Kettawan Aikkarach, Kunlaya Chanlekha, Ratchanee Kongkachuichai and Rin Charoensiri. Effects of Cooking on Antioxidant Activities and Polyphenol Content of Edible Mushrooms Commonly Consumed in Thailand. Pakistan Journal of Nutrition, 20“; 10 (11): 1094-1103

22. Franz M. Medical Nutrition Therapy for Diabetes Melitus and Hypoglicemia of Nondiabetic Origin. In: Mahan LK, Escott-stump S, Janice LR, editors. Krause's Food, Nutrition, and Diet Therapy 13th Edition. Philadelphia: WB Saunders Company; 2012. p.675-708

23. Prameswari Okky, Simon Bambang. Uji Efek Ekstrrak Air Daun Pandan Wangi terhadap Penurunan Kadar Glukosa Darah dan Histopatologi Tikus Diabetes Melitus. J. Pngn dan Agroind. April 2014; 2(2): 16-27

24. Lee H S. Inhibitory activity of Cinnamomum cassiabark derived component against rat lens aldose reductase. J of Pharmacy and Pharmaceutical Sci 2002; 5:226-23

25. Mira L, MT Fernandez, M Santos, et al. Interactions of Flavonoids with Iron and Copper Ions: mechanism for their antioxidant activity. Free Radic Res 2002; 36(11):1199-1208 
26. Sudarmadji S, Haryono B dan Suhardi. Prosedur Analisa untuk Bahan Makanan dan Pertanian. Yogyakarta: Liberty; 1997

27. Persatuan Ahli Gizi Indonesia. Tabel Komposisi Pangan Indonesia. Jakarta; 2009

28. Anton Stephen, Corby K. Martin, Hongmei Han, et al. Effects of stevia, aspartame, and sucrose on food intake, satiety, and postprandial glucose and insulin levels. National Public Access (NIH). 2010 August; 55(1): 37-43

29. Rimbawan Sinagan A. Indeks Glikemik Pangan. Jakarta: Penebar Swadaya; 2004.

30. Fitri R.I. Asupan Energi, Karbohidrat, Serat, Beban Glikemik, Latihan Jasmani dan Kadar Gula Darah padaPasien Diabetes Melitus Tipe 2. Media medika Indonesiana. 2012; 46(2): 121-31

31. Saniah K, Sharifah S.M, MohdLip, Mohd Nazrul, Azizah I. The Potential of Stevia as a Herbal Sugar Substitute in a non-carbonated Drink. Proceedings of National Conference on New Crops and Bioresources; 15-17 Dec.2009; Seremban.p. 220-222 